\title{
Psychological Distress, Family Adjustment and Quality of Life of Mothers of Differentially Disabled Children
}

\author{
Anusha Bhandari ${ }^{1 *}$, Smriti. R. Sethi ${ }^{1}$
}

\section{ABSTRACT}

Every individual faces lot of hurdles in there day to day life, whether working, non-working or even those who are studying. The only factor that sets apart a winner from the others is how they respond to the situation that presents itself in front of them. Disability is considered to be a major problem in today's scenario and is also one major responsibility for those who have or are the care givers for those who have any kind of disability. Quality of life is the Individuals satisfaction (or dissatisfaction) with the cultural or intellectual conditions under which they live. Quality of life not only consists of self satisfaction but also consists of two other factors as well, parenting and Family Adjustment and Psychological Distress. It is very important and a study also proves that involvement of a parent with their child is considered important when it comes to relationship between them and other family members. It helps in understanding the child well and also the similarities and dissimilarities between each other which helps in resolving various parenting and family issues.

The study was done on 80 mothers, 40 working and 40 non-working mothers of differentially disabled children. The age group of mothers varied from 30 - 50 years. And for Children it was 5 - 10 years, which was studied using 3 different questionnaires.

The study conducted shows that there is significant different between quality of life of Working and non-working mothers of differentially abled children, there is a significant Difference in psychological distress of working and non-working mothers of differentially abled children and it also reveals that there is no significant difference between parenting and Family adjustment of working and non-working mothers of differentially abled children.

Keywords: Psychological Distress, Family Adjustment, Quality, Life, Mother, Differentially, Disabled Children

Parenting, Family adjustment and Quality of life these factors play a very important role in every individual's life. These factors are very significant as they play a key role in overall personality development of an individual; it also helps in building up self confidence and also being happy and positive person. Talking about all these factors these variables consists of it

\footnotetext{
${ }^{1}$ Amity Institute of Psychology and Allied Sciences, Amity University, Noida.

**Corresponding Author

(C) 2015 I A Bhandari, S Sethi; licensee IJIP. This is an Open Access Research distributed under the terms of the Creative Commons Attribution License (http://creativecommons.org/licenses/by/2.0), which permits unrestricted use, distribution, and reproduction in any Medium, provided the original work is properly cited.
} 


\section{Psychological Distress, Family Adjustment and Quality of Life of Mothers of Differentially Disabled Children}

clearly shows that how important they are for a women, how it can play wonders in her approach toward life and taking care of the family and surroundings.

Everybody knows how important it is for every mother to maintain a healthy relation with her child and as well as her family. It's her role to protect, take care and maintain healthy relations between the child and the family child and the surroundings, parent and child relations and not forgetting family relations as well. For all this for a women to have a healthy life is very important with good level of confidence, belief in herself so that she can motivate herself every time when situations are bad or dissatisfactory.

It is very difficult and takes lot of courage to maintain relations with normal population, and where there are some disabilities the challenge increases. It is a challenge for any mother to take care of everything when her own child suffers from some or the other disability, not just to save him/her from the society but let family and society accept them the way they are. The further study is based on the same as how a mother is affected when she has a child who is fighting with his/her own disability and how the mother copes with the situation and how everything affects her quality of life , family relations and does she faces any kind of psychological distress.

\section{REVIEW}

Gavidia Payne S and Stoneman Z. (2006) found that the level of marital adjustments of women among couples with children having disabilities analyzed were higher than men. Most of the couples were experiencing average or above average marital adjustments with women contributing more to it.

Leann E. Smith, Jinkuk Hong et. al, (2009) found that, in comparison with a nationally representative sample of mothers of children without disabilities, mothers of adolescent and adult children with ASD spent significantly more time providing childcare and doing chores, and less time in leisure activities. However, mothers of individuals with ASD reported similar levels of positive interactions and volunteerism as the comparison group.

Saddichha S \& Akhtar S (2010) found that, the occurrence of psychosocial problems in epilepsy is common and has severe impact on quality of life. However, the influence of marital adjustment on quality of life in epilepsy and similarities or differences with psychiatric illnesses, with which epilepsy shares several common characteristics, is unknown. The aim of the present study was to therefore explore the relationships between epilepsy, quality of life and marital adjustment and to study differences, if any, with psychiatric illnesses. Couple interventional programs, aimed at improving marital adjustment among spouses may help in improvement of quality of life of patients suffering from epilepsy.

Rabia Tabassum, Naeem Mohsin, (2013) found that, there was high significant correlation between depression and anxiety of parents of children with disability. It did not vary as what disability a child has; the level computed was the same in every sub category. 


\section{Psychological Distress, Family Adjustment and Quality of Life of Mothers of Differentially Disabled Children}

Dhanraj Singh Slathia , (2014) found that, marital and family adjustment are two important factor for working and non-working women. Problems are faced by both who are working and non-working, but significant data revealed that working women faced more problem in marital adjustment as compare to those non-working.

\section{METHODS}

\section{PURPOSE OF THE STUDY}

The purpose of the study was to understand the three major factors in mothers of disabled child. It was conducted to understand the level of psychological distress, family adjustment and quality of life of working and non- working mothers of disabled children. It was hypothesized that there will be a significant difference in quality of life and psychological difference of working and non-working mothers of differentially abled child and there will be no significant difference in their family adjustment.

\section{PARTICIPANTS}

The study was conducted on a total sample of 80 mothers' participants. The sample consisted of (40 working and 40 non-working mothers), the age group was also defined i.e. 30 to 50 years. tTest analyses were computed to study the significant difference of psychological distress, family adjustment and quality of life of working and non-working mothers of differentially abled children.

\section{DATA ANALYSIS}

The descriptive analysis shows that the level of mean of working mothers on psychological distress scale was high as compare to that of non-working mothers (wm -21.22 > nwm-17.95), and also on the scale of quality of life where scores were computed on 4 domains for both working and non-working mothers the results of mean value were, physical - (wm -76.05 > nwm-56.75) high of working mothers, psychological - (wm - 76.37> nwm-56.12) high of working mothers, social - (wm - $74.35>$ nwm - 44.05) high of working mothers and lastly environmental - (wm -76.72 > nwm- 54.12) again high of working mothers. The third test which was to compute family adjustment had two sub categories parenting \& family adjustments, scores were calculated on both and the mean value indicated there was not much of a difference but mean value of working mothers were high on parenting front where in mean value of nonworking mothers were high on family adjustment scale i.e. parenting - (wm -23.75 > nwm 23.02) \& family adjustment - (wm - $12.85<$ nwm -13.67). 
TABLE: 1.1 - Comparison of MEAN, SD of Kessler Psychological Distress Dimensions between Working and Non - Working Mothers

\begin{tabular}{|c|l|l|l|l|l|}
\hline & \multicolumn{2}{|c|}{ Working Mothers } & \multicolumn{2}{c|}{ Non- Working Mothers } & \multirow{2}{*}{$\begin{array}{c}\text { t } \\
\text { Value } \\
\begin{array}{c}\text { Kessler } \\
\text { Psychological } \\
\text { Distress }\end{array}\end{array}$} \\
\hline & Mean & $\begin{array}{c}\text { Standard } \\
\text { Deviation }\end{array}$ & Mean & $\begin{array}{c}\text { Standard } \\
\text { Deviation }\end{array}$ & \\
\hline & 21.22 & 2.29 & 17.95 & 2.30 & 6.13 \\
\hline
\end{tabular}

${ }^{*} p<.05, * * p<.01$

Table 1 shows the comparison of Psychological distress, Mean and SD of working and non working mothers of differentially disabled children. As observed from the table, mean value of working mothers is on the higher end as compare to the non-working mothers which shows lower distress. As the t value got computed and t critical at .05 level is 1.990, hence there is a significant difference in psychological difference of working and non-working mothers. As per the table value of $t-6.13>1.990$ at .05 level.

Graph -2.1: Psychological Distress Dimension of Working And Non-Working Mothers

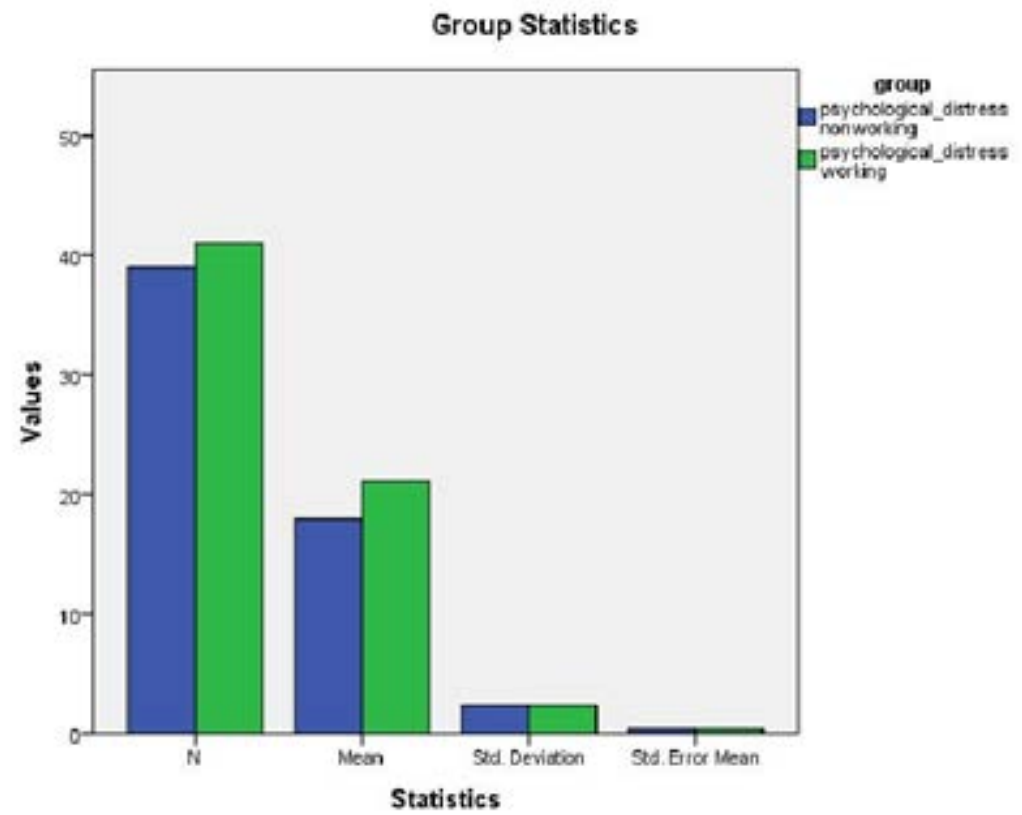

The above mentioned graph represents the mean values for working and non-working mothers on psychological distress scale. 
Table: 1.2 - Comparison of MEAN, SD of Quality of Life Dimensions between Working and Non - Working Mothers

\begin{tabular}{|l|l|l|l|l|l|}
\hline \multicolumn{3}{|l|}{ Working Mothers } & \multicolumn{2}{l|}{ Non Working Mothers } & t Value \\
\cline { 1 - 5 } $\begin{array}{l}\text { Domains of } \\
\text { QOL }\end{array}$ & Mean & $\begin{array}{l}\text { Standard } \\
\text { Deviation }\end{array}$ & Mean & $\begin{array}{l}\text { Standard } \\
\text { Deviation }\end{array}$ & \\
\hline Physical & 76.05 & 14.37 & 56.75 & 9.14 & 7.24 \\
\hline Psychological & 76.37 & 15.65 & 56.12 & 9.45 & 6.56 \\
\hline Social & 74.35 & 22.70 & 44.05 & 16.88 & 6.29 \\
\hline Environmental & 76.72 & 14.62 & 54.12 & 8.20 & 8.44 \\
\hline
\end{tabular}

Table 2 shows the comparison of QOL dimensions, mean and SD between working and nonworking mothers of differentially disabled children. As per the calculation the mean value of working mothers is on the higher side a compare to the non-working mothers which indicates higher distress among the working mothers. As per the table the value of $t$ in all the domains is greater than the value of $t$ at .05 levels i.e. 1.990. Hence, there is a significant difference in quality of life of working and non-working mothers in all domains as they are greater than the $t$ value at .05 levels.

As per the table value of $t$ in all domains:

- Physical - 7.249>1.990

- Psychological - 6.566>1.990

- Social - 6.296>1.990

- Environment - 8.444>1.990

Graph - 2.2: Physical, Psychological, Social \& Environmental Dimension of Quality of Life of Working and Non-Working Mothers

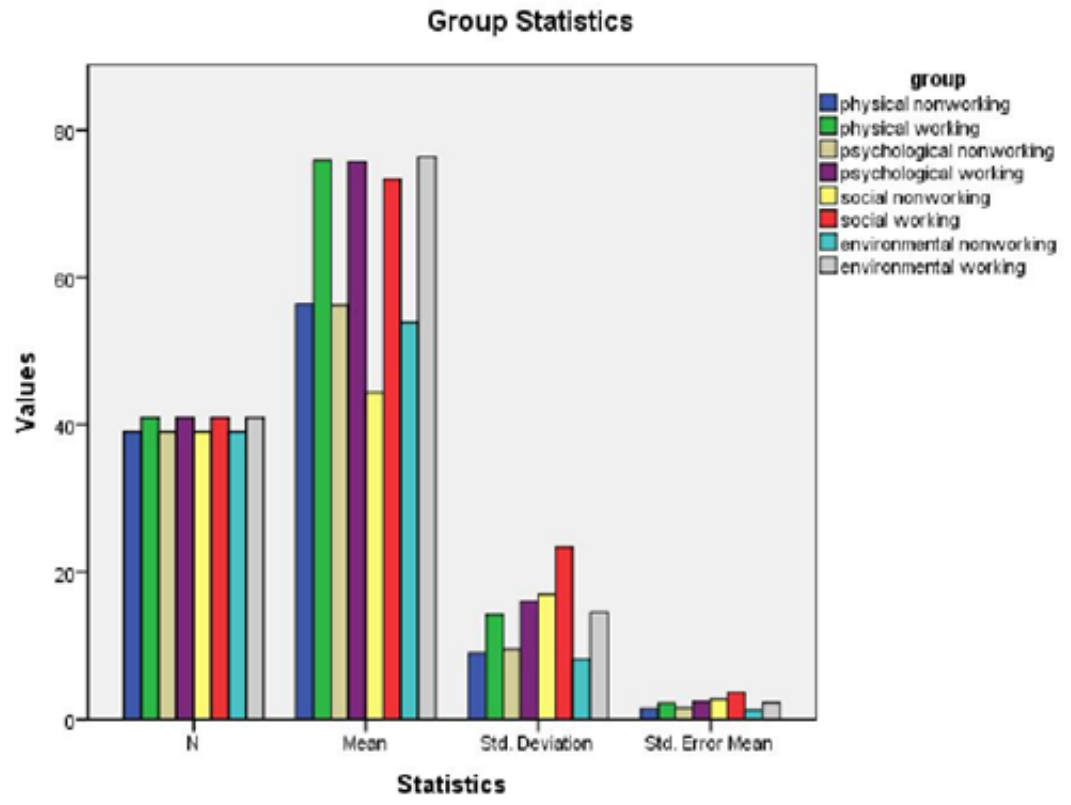

The above mentioned graph represents the quality of life on four specific sub-domains of working and non-working mothers. 
Table:1.3- Comparison of MEAN AND SD value of Parenting and Family Adjustment Scale between Working and Non-Working Mothers Working Mothers

\begin{tabular}{|l|l|l|l|l|l|}
\hline & \multicolumn{2}{|l|}{ Working Mothers } & \multicolumn{2}{l|}{ Non Working Mothers } & t Value \\
\hline PAFAS & Mean & $\begin{array}{l}\text { Standard } \\
\text { Deviation }\end{array}$ & Mean & $\begin{array}{l}\text { Standard } \\
\text { Deviation }\end{array}$ & \\
\hline Parenting & 23.75 & 4.55 & 23.02 & 4.09 & .728 \\
\hline $\begin{array}{l}\text { Family } \\
\text { Adjustment }\end{array}$ & 12.85 & 3.79 & 13.67 & 4.49 & 1.065 \\
\hline
\end{tabular}

${ }^{*} \mathrm{p}<.05,{ }^{* *} \mathrm{p}<.01$

Table 3 shows the comparison of PAFAS which consists of both parenting and family adjustment as sub-scale. According to the above table the level of mean of parenting style in working mothers is a little high as compare to the non-working mothers, whereas the level of mean of family adjustment in working mothers is little low as compare to the non-working mothers.

As per the table the value of $t$ on both domains is less than the $t$ value at 0.05 level i.e. 1.990, hence, there is no significant difference between working and non-working mothers on PAFAS, parenting \& family adjustment scale.

As per the table the $t$ value of 2 domains:

- Parenting - .728<1.990

- Family Adjustment - $1.065<1.990$

Graph - 2.3: Parenting \& Family Adjustment Dimension of Working and Non-Working Mother

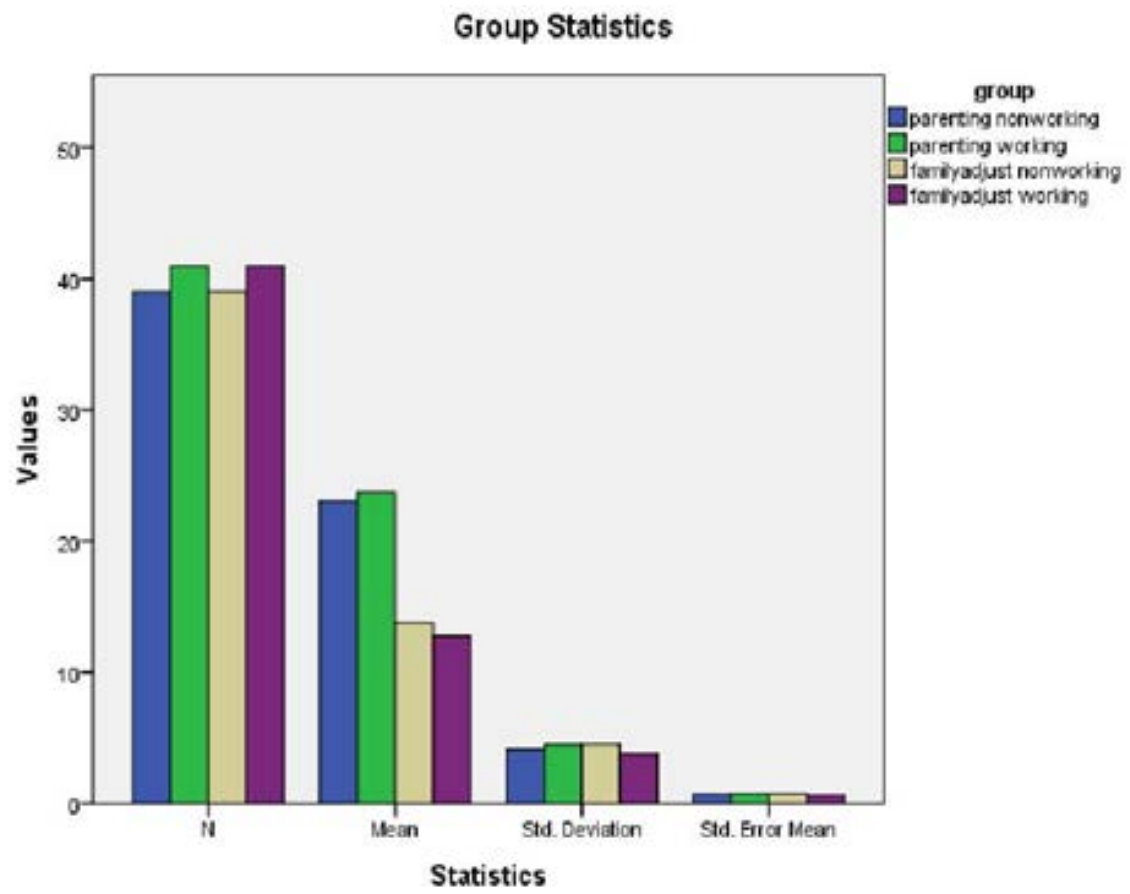

The above mentioned graph represents the mean value of working and non-working mothers on parenting and family adjustment scale. 


\section{Psychological Distress, Family Adjustment and Quality of Life of Mothers of Differentially Disabled Children}

\section{CONCLUSION}

The present study aimed to study the Psychological Distress, Quality of life \& Family Adjustment of working and non-working mothers of differentially abled children. The sample comprises of 80 mothers ( 40 working and 40 non-working mothers), Mean and SD was computed and t test analysis was done to see the significant difference between the parameters of all the variables in relation with working and non-working mothers.

All the three parameters have a significant impact on over-all personality of an individual, if the level is low for all the three then there can be massive difference in the personality which directly or indirectly affect the individual on both personal and professional front. All the three parameters were studied in relation with mothers (working \& non-working), keeping in mind they are initial care givers of children (disabled or normal).

There are various researches that have been done in past which have explained the impact of psychological distress, parenting and family adjustment and quality of life of working mothers.

There was a study done by Vidhya Ravindranadan and Raju, S in year 2008 and they founded that, the parents of children who are differentially abled are primarily different from those of normal children, irrespective of what category of disability the child falls in. It was also studied and found that the condition of a child does affect the condition of the parents equally.

There was another study done on marital and family adjustment by Dhanraj Singh Slathia in year 2014 and they founded that , marital and family adjustment are two important factor for working and non-working women. Problems are faced by both who are working and non- working, but majorly data revealed that working women faced more problem in marital adjustment as compare to those non-working mothers.

It is important for women to have a healthy lifestyle as it adds up to the healthy environment at home as well as the surroundings. There are various studies done on how the mental imbalance in women affects the environment around her and how it also affects her personally too.

Studies above have proved that how family and parenting adjustment, quality of life and psychological distress play an important role in life of women and how positively and negatively it can affect the family life, child parent relationship and the surroundings.

\section{REFERENCES}

Adegoke AA (1987). Female labour force participation and marriage happiness: A study of selected women in Ilorin and Ibadan. Nig. J. Guid. Couns. 3(1):132-140.

Afzal, A., Zahra, R., Mehmood, B., \& Hussain, S. (2010). European journal of Social Sciences, 18(1), 130-145.

Aneesa A, Najma M, Noreen A 2013. Family communication and family system as the predictors of family satisfaction in adolescents. Science Journal of Psychology, 13(6): 253- 258.

Armistead L, Wierson M, Forehand R 1990. Journal of Early Adolescence, 10(3): 260-278.

Bromet, E., Gluzman, S., Paniotto, V., Webb, C., Tintle, N., Zakhozha, V., \& Schwartz, J. 


\section{Psychological Distress, Family Adjustment and Quality of Life of Mothers of Differentially Disabled Children}

(2005). Epidemiology of psychiatric and alcohol disorders in Ukraine: Findings from the Ukraine World Mental Health survey. Social Psychiatry and Psychiatric Epidemiology, 40, 681-690.

Buki, L. P., Ma, T. C., Strom, R. D., \& Strom, S. K. (2003). Chinese immigrant mothers of adolescents: Self-perceptions of acculturation effects on parenting. Cultural Diversity and Ethnic Minority Psychology, 9(2), 127-140.

Buriel, R., Perez, W., De Ment, T., Chavez, D., \& Morgan, V. (1998). The relationship of language brokering to academic performance, biculturalism, and self-efficacy among Latino adolescents. Hispanic Journal of Behavioral Sciences, 20, 283-297.

Cheung, B. Y., \& Chudek, M. (2011). Evidence for a sensitive period for acculturation: Younger immigrants report acculturating at a faster rate. Psychological Science, 22(2), 147-152.

Chiswick, B. R. (1993). Soviet Jews in the United States: An analysis of their linguistic and economic adjustment. International Migration Review, 27(2), 260-286.

Chiswick, B. R., Lee, Y. L., \& Miller, P. W. (2005). A longitudinal analysis of immigrant occupational mobility: A test of the immigrant assimilation hypothesis. International Migration Review, 39, 2, 332-353.

Choi, H., \& Dancy, B. L. (2009). Korean American adolescents' and their parents' perceptions of acculturative stress. Journal of Child and Adolescent Psychiatric Nursing, 22, 203-210.

Chow, J., Jaffe, K., \& Snowden, L. R. (2003). Racial/ethnic disparities in the use of mental health services in poverty areas. American Journal of Public Health, 93, 792-797.

Clark, W. A. V., \& Patel, S. (2004). Residential choices of the newly arrived foreign born: Spatial patterns and the implications for assimilation. On-Line Working Paper Series, University of California, Los Angeles.

Cohen, S. M., \& Horenczyk, G. (1999). National variations in Jewish identity: Implications for Jewish education. New York: State University of New York Press.

Combs, D. R., Penn, D. L., Michael, C. O., Basso, M. R., Wiederman, R., Siebenmorgan, M., \& Chapman, D. (2009). Perceptions of hostility by persons with and without persecutory delusions. Cognitive Neuropsychiatry, 14, 30-52.

Conger, K. J., Reuter, M. A., \& Conger, R. D. (2000). The role of economic pressure in the lives of parents and their adolescents: The family stress model. In L. J.

Cortes, D. E., Rogler, L. H., \& Malgady, R. G. (1994). Biculturality among Puerto Rican adults in the United States. American Journal of Community Psychology, 22,707- 721.

Costigan, C. L., \& Dokis, D. P. (2006). Relations between parent-child acculturation differences and adjustment within immigrant Chinese families. Child Development, 77(5), 12521267.

Courtenay, W. H. (2000). Engendering health: A social constructionist examination of men's health beliefs and behaviors. Psychology of Men and Masculinity, 1(1), 4- 15.

Crockett \& R. J. Silbereisen (Eds.), Negotiating adolescence in times of social change (pp. 201223). Cambridge, England: Cambridge University Press.

Cross, T. L. (2003). Culture as a resource for mental health. Cultural Diversity and Ethnic Minority Psychology, 9(4), 354-359.

Cubis, J., Lewin, T., \& Dawes, F. (1989). Australian adolescents' perceptions of their parents. Australian and New Zealand Journal of Psychiatry, 23, 35-47.

Delgado, G. C. (1994). Russian refugee families: Accommodating aspirations through education. Anthropology and Education Quarterly, 25(2), 137-155.

Delgado, G.C. (1994). Spanish-speaking families' involvement in schools. In C.L. Fagnano \& B. 
Z. Weber (Eds.), School, family, and community interaction: A view from the firing lines (pp.85-98). San Francisco: Westview Press.

DeMeyer M. K. (1979). Parents and Children in Autism. V. H. Winston \& Sons, Washingto.

Ding, H., \& Hargraves, L. (2008). Stress-associated poor health among adult immigrants with a language barrier in the United States. Journal of Immigrant Minority Health, 11(6), 446452.

Dinh, K. T., \& Nguyen, H. H. (2006). The effects of acculturative variables on Asian American parent-child relationships. Journal of Social and Personal Relationships, 23, 407- 426.

Dinh, K. T., Sarason, B. R., \& Sarason, I. G. (1994). Parent-child relationships in

Dion, K. L., Dion, K.K., \& Pak, A. (1992). Canadian Journal of Behavioral Science, 24, 517536.

Dohrenwend, B. P. (2000). Journal of Health and Social Behavior, 41, 1-19. du Plessix Gray, F. (1990). Soviet women: Walking the tightrope. New York, NY: Doubleday.

Vietnamese immigrant families. Journal of Family Psychology, 8(4), 471-88. 